\title{
The Effect of Teaching Materials Based on Local Value Integrated by Character Education through PBL Models on Students' High Order Thinking Skill
}

\author{
Khairil Hadi ${ }^{1}$, Dazrullisa ${ }^{2}$, Hasruddin $^{3}$, Binari Manurung ${ }^{4}$ \\ ${ }^{1}$ Department of Biology education, STKIP Bina Bangsa Meulaboh, Aceh, Indonesia, \\ ${ }^{2}$ Department of Mathematics education, STKIP Bina Bangsa Meulaboh, Aceh, Indonesia, \\ ${ }^{3}$ Dr., Department of Biology-Universitas Negeri Medan, Medan, North Sumatera, Indonesia \\ ${ }^{4}$ Prof. Dr. rer. nat, Department of Biology-Universitas Negeri Medan, North Sumatera, Indonesia, \\ Email: 1herilbio@yahoo.co.id,2dazrullisa@yahoo.co.id,3hasruddin_lbsmdn@yahoo.com, \\ 4binarimanurung@unimed.ac.id
}

\begin{abstract}
:
This study aims to know the effect of biology teaching materials based on local wisdom integrated character education through problem-based learning models on students' high order thinking skills. This study uses a quantitative approach and belongs to the type of quasi-experimental research. The research design is the one group's pre-test-post-test design. The research sample consisted of 111 students from five schools in West Aceh. The data collection used a validation sheet of the lesson plan and high-level thinking test questions. Research data was analysed by statistical average values, normality, homogeneity, and paired sample $t$ test. The research results indicated that the using of biology teaching materials based on local wisdom integrated with character education through problem based learning models has a very significant effect on students' high-level thinking $(P=0.00)$. The instruction that used local wisdom, character education and PBL model have a positive role in the motivating of students, cooperation, discipline, fond of reading, student achievement, and problems solving in accordance with the expected learning outcomes.
\end{abstract}

Keywords :

teaching materials, local wisdom, character education, PBL models, high-level thinking

\section{Introduction}

The integration of local wisdom is carried out to present a real learning process so students can easily understand the material presented. Furthermore, local wisdom is important for students to stay close to the school and for teachers to engage with most learners (Pornpimon et al. 2014). Culture is potential to be developed in learning science. Physical environment and social culture have a variety of potential aspects that can be integrated as supplementary teaching materials of science (Parmin et al. 2015). Culture is a complex concept system, include; values, norms, beliefs and practices that is handed down from generation to generation (Gondwe and Nancy. 2014). The research result of Sharif and Gisbert (2015) showed that the cultural has impact on teacher to design the instruction.

Viewed in terms of the curriculum that applies in Indonesia education today is the 2013 curriculum which emphasizes one of them is the application of character education in schools. In Indonesia, character values based on national culture consist of religious, honest, tolerance, discipline, hard work, creative, independent, democratic, curiosity, national spirit, nationalism, respect for achievement, friendly/communicative, peace-loving, fond of reading environmental care, social care and responsibility. The implementation of these characters in learning biology is by linking learning material in accordance with predetermined characters. One of the main criteria of 'character strength' is that the character contributes greatly to fully actualize one's potentials and ideals in building a good life, that is beneficial to oneself and to others (Philips, 2008; Peterson \& 
Seligman, 2004). Katilmis, A., et al (2011) stated that the integration of character education can have a positive impact on students, such as: (1) Character education program affects the students positively and considerably in a statistical way to gain scientific value., (2) Character education program affects the students positively and significantly in a statistical way to gain the value for being justness., (3) Character education program affects the students positively and considerably in a statistical way to gain the peace value., and (4) Character education program affects the students' academic success positively and significantly in a statistical way. Furthermore, research that be done by Davidson et al (2007) found that there was the characters role in all types of school achievement, both curricular and non-curricular. Investigation conducted by Benninga et al. (2003) regarding the relationship between the implementation of character education and academic achievement in elementary schools in California, United States concluded that primary schools that carry out character education seriously and well designed tend to have high academic achievement.

Whereas in terms of learning objectives, biology which is part of science should be taught using a scientific approach, one of the learning models of the scientific approach is the model of problem based learning (Hadi, K et al. 2019). Problem-based learning is also a model which in its implementation uses problems. The problems that arise are inseparable from the discussion or material being taught. However, it would be better if the problems raised are in accordance with the material and related to real life (facts).

Some advantages in the application of learning by linking science, technology, environment and society among them will make students become well, namely the attitude of students more concerned about the environment (Kim \& Roth, 2008). Teaching material developed in this study was developed by following the steps, namely: (a) Analysing of material content, (b) Analysing of local wisdom in West Aceh, (c) Deepening of character values, and (d) writing content according to PBL syntex. This research equips students and teachers to deal with changes in society, especially changes in curriculum and labor market competition by not leaving culture, character, and knowledge. The development of teaching materials based on local wisdom integrated with character education through the application of the PBL model is expected to develop the potential and improve the ability to think at a higher level character of learners.

\section{Methodology}

\subsection{Research Design}

This study uses a quantitative approach with the aim to find out how does the influence of teaching materials development on students' higher-level thinking skills. The type of this research is a quasi-experimental with design one group's pre-test-post-test that provides tests in the form of pre-test at the beginning of the treatment and post-test after treatment.

\subsection{Population and Sample}

This research was conducted in five senior high schools (SMA) in Aceh in students of X class grades of science. Determination of the sample is done using random sampling techniques. The population number was 284 students, meanwhile its sample was 111 students (Table 1). 
Table 1. Population and research sample numbers

\begin{tabular}{|c|c|c|c|c|}
\hline \multirow{2}{*}{ School } & \multicolumn{2}{|c|}{ Population } & \multicolumn{2}{|c|}{ Sample } \\
\hline & Class & Number & Class & Number \\
\hline \multirow{3}{*}{ School A } & $\mathrm{X}_{1}$ Science & 27 & \multirow{3}{*}{$\mathrm{X}_{1}$ Science } & \multirow{3}{*}{27} \\
\hline & $\mathrm{X}_{2}$ Science & 25 & & \\
\hline & $\mathrm{X}_{3}$ Science & 27 & & \\
\hline \multirow{2}{*}{ School B } & $\mathrm{X}_{1}$ Science & 20 & \multirow{2}{*}{$\mathrm{X}_{2}$ Science } & \multirow{2}{*}{20} \\
\hline & $\mathrm{X}_{2}$ Science & 20 & & \\
\hline \multirow{3}{*}{ School C } & $\mathrm{X}_{1}$ Science & 20 & \multirow{3}{*}{$\mathrm{X}_{2}$ Science } & \multirow{3}{*}{20} \\
\hline & $\mathrm{X}_{2}$ Science & 20 & & \\
\hline & $\mathrm{X}_{3}$ Science & 19 & & \\
\hline \multirow{3}{*}{ School D } & $\mathrm{X}_{1}$ Science & 21 & \multirow{3}{*}{$\mathrm{X}_{3}$ Science } & \multirow{3}{*}{24} \\
\hline & $\mathrm{X}_{2}$ Science & 23 & & \\
\hline & $\mathrm{X}_{3}$ Science & 24 & & \\
\hline \multirow{2}{*}{ School E } & $\mathrm{X}_{1}$ Science & 20 & \multirow{2}{*}{$\mathrm{X}_{1}$ Science } & \multirow{2}{*}{20} \\
\hline & $\mathrm{X}_{2}$ Science & 18 & & \\
\hline Five Schools & Total & 284 & Total & 111 \\
\hline
\end{tabular}

\subsection{Instrument and Technique of Data Analysis}

The research instrument used in this study was the validation sheet of the lesson plan, the validation sheet of the high-level thinking ability test and the achievement test.

a. Validation Sheet of Lesson Plan

The lesson plan (RPP) validation sheet is needed to measure the extent of the achievement and suitability of the designed lesson plan. Validation is carried out by a team of experts in the field of RPP with indicators of the completeness of the lesson plan, the compliance of the RPP, integration of local wisdom, integration of character education, and the syntax conformity of the Problem Based Learning (PBL) model. The validation sheet uses a rating scale 1-4.

b. Validation Sheet of Questions Test and Trials of Questions Test

The questions test validation sheet consists of substance requirements, construction requirements, and language requirements. Validation in this study was carried out by a team of experts using a rating scale 1-4. After a revision of the validator's advice, the questions were tested on 12 students from five schools that were not included in the research sample.

c. High-Level Thinking Skills Test

The high-level thinking ability test in this study uses test technique in the form of multiple choice. Test questions are prepared based on local wisdom integrated with character education on biodiversity material. The test questions in this study consisted of 20 pre-test and 20 post-test 
questions. Criteria for high-level thinking test questions include analysis (C4), synthesis (C5) and evaluation (C6).

\subsection{Data analysis technique}

Data analysis techniques in research used descriptive and inferential statistics. Descriptive statistics are used to analyze the results of the validator's assessment into the lesson plans and for test questions by using a statistical formula of the average value and then interpreting it in the form of a statement (Table 2). Inferential statistic analysis is performed to test the data of students' highlevel thinking test results. The analysis included reliability and normality tests that be conducted with the Kolmogorov-Smirnov approach, while a homogeneity test was carried out with the Levene's test approach (Table 3). After the prerequisites are fulfilled then the test is done using paired sample test using the SPSS program.

Table 2. Conversion values using scala 1-4

\begin{tabular}{ccc}
\hline \multirow{2}{*}{ Score } & \multicolumn{2}{c}{ Interpretasi Data } \\
\cline { 2 - 3 } & Lesson Plan & Question \\
\hline $\mathrm{X} \geq 3,25$ & Valid & Valid \\
\hline $3,25>\mathrm{X} \geq 2,5$ & Valid enough & Valid enough \\
\hline $2,5>X \geq 1,75$ & Less Valid & Less Valid \\
\hline $2,5>X \geq 1,75$ & Invalid & Invalid \\
\hline
\end{tabular}

Table 3. Interpretation of the test values for reliability, normality, homogeneity and paired sample test

\begin{tabular}{lcc}
\hline & Data Interpretation & Description \\
\hline \multirow{2}{*}{$\begin{array}{l}\text { Data Reliability } \\
\text { Test }\end{array}$} & Cronbach's Alpha $>\alpha 0,05$ & Reliable \\
\cline { 2 - 3 } & Cronbach's Alpha $<\alpha 0,05$ & Not Reliable \\
\hline $\begin{array}{l}\text { Data Normality } \\
\text { Test }\end{array}$ & Sig. (2-tailed) $>\alpha 0,05$ & Normal \\
\cline { 2 - 3 } $\begin{array}{l}\text { Data } \\
\text { Homogeneity Test }(2 \text {-tailed) }<\alpha 0,05\end{array}$ & Sot Normal \\
\cline { 2 - 3 } & Sig. (2-tailed) $>\alpha 0,05$ & Homogeneous \\
\hline \multirow{2}{*}{ Paired SampleTest $)<\alpha 0,05$} & Not Homogeneous \\
\cline { 2 - 3 } & Sig. (2-tailed) $>\alpha 0,05$ & There are differences \\
& Sig. (2-tailed) $<\alpha 0,05$ & $\begin{array}{c}\text { There are not } \\
\text { differences }\end{array}$ \\
\hline
\end{tabular}

\section{Discussion}

\subsection{Validation Results of Learning Implementation Plan on Biodiversity Material by Expert}

The validation result of learning implementation plan by expert is presented in Table 4 . 
Table 4. The Learning Implementation Plan Validation Results

\begin{tabular}{|c|c|c|c|c|c|c|c|}
\hline \multirow{2}{*}{ Indicator } & \multicolumn{4}{|c|}{ Validator } & \multirow{2}{*}{$\begin{array}{l}\text { Total } \\
\text { score }\end{array}$} & \multirow{2}{*}{$\begin{array}{l}\text { Avera } \\
\text { ge } \\
\text { score }\end{array}$} & \multirow{2}{*}{ Criteria } \\
\hline & $\mathrm{I}$ & II & III & IV & & & \\
\hline Completeness & 4.0 & 4.0 & 4.0 & 4.0 & 16.0 & 4.0 & Valid \\
\hline $\begin{array}{l}\text { Appropriate } \\
\text { content }\end{array}$ & $\begin{array}{c}3.6 \\
9\end{array}$ & 3.77 & 3.86 & 3.86 & 15.18 & 3.8 & Valid \\
\hline $\begin{array}{l}\text { Integration of } \\
\text { local wisdom }\end{array}$ & 4.0 & 4.0 & 4.0 & 4.0 & 16.0 & 4.0 & Valid \\
\hline $\begin{array}{l}\text { Integration } \\
\text { character } \\
\text { education }\end{array}$ & 4.0 & 3.5 & 4.0 & 4.0 & 15.5 & 3.88 & Valid \\
\hline PBL Syntax & 3.5 & 4.0 & 4.0 & 3.5 & 15.0 & 3.75 & Valid \\
\hline \multicolumn{5}{|c|}{ Total score } & \multicolumn{3}{|c|}{19.43} \\
\hline \multicolumn{6}{|c|}{ Average score } & 3.89 & Valid \\
\hline
\end{tabular}

Validation result on Table 4 shows that the learning implementation plan by expert is valid with an average score 3.89 .

\subsection{Results of Pre-test and Post-Test Biological Validation Results for High-Level Thinking on Diversity Materials}

The validation result of expert on pre-test and post-test of biological achievement test are presented in Table 5 and Table 6.

Table 5. The validation results of the pre-test questions

\begin{tabular}{lccccccc}
\hline \multirow{1}{*}{ Indicator } & \multicolumn{5}{c}{ Validator } & \multicolumn{3}{c}{$\begin{array}{c}\text { Total } \\
\text { score }\end{array}$} & $\begin{array}{c}\text { Avera } \\
\text { ge } \\
\text { score }\end{array}$ & Criteria \\
\cline { 2 - 7 } & I & II & III & IV & & Valid enough \\
\hline $\begin{array}{l}\text { Substance } \\
\text { Requirements }\end{array}$ & 3.0 & 3.2 & 3.2 & 3.32 & 12.72 & 3.18 & Valid \\
\hline $\begin{array}{l}\text { Construction } \\
\text { Requirements }\end{array}$ & 3.4 & 3.2 & 3.4 & 3.32 & 13.32 & 3.33 & Valid \\
\hline $\begin{array}{l}\text { Language } \\
\text { Requirements }\end{array}$ & 3.2 & 3.3 & 3.22 & 3.4 & 13.12 & 3.28 & Valid \\
\hline $\begin{array}{l}\text { Total score } \\
\text { Average score }\end{array}$ & 3.2 & 3.23 & 3.27 & 3.35 & 13.05 & 3.26 & \\
\hline Criteria & $\begin{array}{c}\text { Valid } \\
\text { enough }\end{array}$ & $\begin{array}{c}\text { Valid } \\
\text { enough }\end{array}$ & Valid & $\begin{array}{c}\text { Valid } \\
\text { enough }\end{array}$ & & Valid & \\
\hline
\end{tabular}


Table 5 shows that the pre-test question of high level thinking on biodiversity material is valid with an average value of 3.26 .

Table 6. Validation Results of test questions of Post-test

\begin{tabular}{|c|c|c|c|c|c|c|c|}
\hline \multirow{2}{*}{ Indicator } & \multicolumn{4}{|c|}{ Validator } & \multirow{2}{*}{$\begin{array}{l}\text { Total } \\
\text { score }\end{array}$} & \multirow{2}{*}{$\begin{array}{l}\text { Aver } \\
\text { age } \\
\text { score }\end{array}$} & \multirow{2}{*}{ Criteria } \\
\hline & $\mathrm{I}$ & II & III & IV & & & \\
\hline $\begin{array}{l}\text { Substance } \\
\text { Requirements }\end{array}$ & 3.2 & 3.0 & 3.23 & 3.4 & 12.83 & 3.21 & Valid enough \\
\hline $\begin{array}{l}\text { Construction } \\
\text { Requirements }\end{array}$ & 3.09 & 3.31 & 3.54 & 3.51 & 13.45 & 3.36 & Valid \\
\hline $\begin{array}{l}\text { Language } \\
\text { Requirements }\end{array}$ & 3.02 & 3.5 & 3.32 & 3.5 & 13.34 & 3.34 & Valid \\
\hline Total score & 9.31 & 9.81 & 10.09 & 10.41 & 39.62 & 9.91 & \\
\hline Average score & 3.1 & 3.27 & 3.36 & 3.47 & 13.21 & 3.30 & Valid \\
\hline
\end{tabular}

Table 6 shows that post-test test question of high-level thinking on biodiversity material is valid with an average value of 3.30 .

\subsection{Test Results of Reliability Testing of Pre-test and Post-test Questions}

The result of reliability testing on pre-test and post test questions are presented in Table 7 and Table 8.

Table 7. Data of Reliability Testing Result on Pre-test Questions

\begin{tabular}{lc}
\hline Mean & 10.65 \\
\hline Variance & 7.29 \\
\hline Std. Deviation & 2.70 \\
\hline Cronbach's Alpha & .38 \\
\hline Cronbach's Alpha Based on Standardized Items & .39 \\
\hline N of Items & 20 \\
\hline
\end{tabular}

Table 7 shows that the Cronbach's Alpha value is 0.38 , meanwhile the $r$ table value of the 20 items is 0.35 . This results states that pre-test questions is reliable where the score of Cronbach's Alpha of pre-test is bigger (0.38) than the score of its $r$ table (0.35).

Table 8. Data of Reliability Testing result of Post-test Questions

\begin{tabular}{ll}
\hline Mean & 9.40 \\
\hline Variance & 8.35 \\
\hline Std. Deviation & 2.89 \\
\hline
\end{tabular}


Cronbach's Alpha $\quad .41$

Cronbach's Alpha Based on Standardized Items $\quad .42$

$\mathrm{N}$ of Items

20

Table 8 shows that the Cronbach's Alpha value for Post-test question is 0.41 and while for its $r$ Table is 0.35 . Therefore, the post test question is also reliable because the score of Cronbach's Alpha post test question is also bigger (0.41) than its $r$ table score (0.35).

\subsection{Pre-Test and Post-Test Results of High-Level Thinking on Biodiversity Materials}

The result of normality and homogeneity testings on student achievement data in pre-test and post-test are presente

Table 9. Test Data Normality Using One-Sample Kolmogorov- Smirnov Test

\begin{tabular}{|c|c|c|c|}
\hline & & PRE-TEST & POSTTEST \\
\hline $\mathrm{N}$ & & 111 & 111 \\
\hline \multirow[b]{2}{*}{ Normal Parameters ${ }^{a}$} & Mean & 37.70 & 80.59 \\
\hline & $\begin{array}{l}\text { Std. } \\
\text { Deviation }\end{array}$ & 10.99 & 10.59 \\
\hline \multirow{3}{*}{$\begin{array}{l}\text { Most Extreme } \\
\text { Differences }\end{array}$} & Absolute & .11 & .12 \\
\hline & Positive & .11 & .12 \\
\hline & $\overline{\text { Negative }}$ & -.07 & -.07 \\
\hline Kolmogorov-Smirnov Z & & 1.16 & 1.31 \\
\hline Asymp. Sig. (2-tailed) & & .13 & .06 \\
\hline
\end{tabular}

a. Test distribution is Normal.

The testing result that be showed in Table 9 states that both the pre-test and post-test data are normally distributed (P pre-test $=0.13$ and $P$ post-test $=0.06$ ).

Table 10. Homogeneity Test Data Using Test of Homogeneity of Variances

\begin{tabular}{lcccc}
\hline & Levene Statistic & df1 & df2 & Sig. \\
\hline Pre-test & 1.30 & 4 & 106 & .27 \\
\hline Post-test & .73 & 4 & 106 & .57 \\
\hline
\end{tabular}


The result of homogeneity testing as shows in Table 10 states that both pre-test and posttest data are homogeneous (P Pre-test $=0.27$ and P Post-test $=0.57$ ).

\subsection{Differences Testing of High Level Thinking of Students between Pre-test and Post-test}

Differences testing of student achievement, in this case the high level thinking of student in learning process between pre-test (before using the teaching material that be developed) and post-test (after using the teaching material that be developed) are showed in Table 11.

Table 11. The differences testing of student high level thinking by using the t-pair sample test

\begin{tabular}{lcc} 
Paired Differences & Pre-test - Post-test \\
\hline Mean & -42.88 \\
\hline Std. Deviation & 7.05 \\
\hline Std. Error Mean & .67 \\
\hline 95\% Confidence Interval & Lower & -44.21 \\
\cline { 2 - 3 } of the Difference & Upper & -41.55 \\
\hline $\mathrm{t}$ & & -64.02 \\
\hline df & & 110 \\
\hline Sig. (2-tailed) & & \\
\hline
\end{tabular}

The result of testing as be displayed in Table 11 shows that there is significant differences of students high level thinking before using the teaching material that be developed (pre-test scores) and after using the teaching material that be developed (post-test scores) $(\mathrm{P}=0.00)$. This research finding states that there is very significantly effect of teaching materials that be developed and be carried out in PBL model in learning process on students high level thinking in the senior high school.

Innovations in learning have a positive impact on student learning outcomes. Learning innovations as outlined in textbooks can provide better learning outcomes, increase the efficiency and effectiveness of learning towards renewal (Folb et al, 2011). According to Glynn \& Winter (2004), learning using real world contexts and the integration of various sciences, will influence the mastery of students' concepts. However, learning innovation must be done by analysing the needs, namely the analysis of student character, analysis of the school environment, analysis of learning tools, and analysis of learning materials. This is necessary in order to produce innovations that are ready to fit the problems found in the field.

The results of this study indicate that the use of teaching materials based on local wisdom and national character values through the PBL model can affect high-level thinking where the difference between the pre-test and post-test scores is 42.89 (37.70-80.59). Aside from innovations made in learning, the experience of the teacher also plays an active role in determining student learning outcomes. This is evident from the learning outcomes between students taught by teachers who have been certified and those who have not been certified. 
Teaching materials based on local wisdom and character education through problem based learning models in this study are teaching materials on biodiversity material developed by containing local wisdom, national character values, and student worksheets which adopt the PBL model.

Learning by integrating character values also plays a good role in the learning process. Students seem to work together, are disciplined, love to read, and appreciate achievement. Working together can be seen when solving problems raised by the teacher, then students work in groups. Discipline is seen when students work on assignments on the time specified by the teacher. Reading fondness is seen when students look for references in the library and cell phones are used to look for other references. Appreciating achievement is seen when students make presentations where students have determined their assignments which will be explained during the presentation. If the teacher consistently integrates character education in the subject matter, then it is likely to produce students who have good character (Sugiyo, R \& Purwastuti, A. L. 2017). Berkowitz (2007) states that character education can effectively have a positive impact on various behaviours, such as perseverance and courage. Triatmanto (2010) who explained that one of the goals of character integration in learning activities is to make students master the competencies (materials) which are targeted.

The success in this study was also influenced by the use of learning models. Students should learn the content and procedures of science while also developing "an epistemic knowledge of how such procedures warrant the claims that scientists advance" (Osborne, 2013). Cognitive achievement of students increased because of the motivation and strategy in learning process (Tosun and Taskesenligil, 2011). The problem based learning model used in this study also has a positive impact. Where students look enthusiastic in solving problems as a group and interpret group work in accordance with the expected learning outcomes. This finding is aligned to the findings of researchers (Arantes do Amaral \& Matsusaki, 2017), who point out that PBL handson approach develops skills such as critical thinking, the ability to work in groups effectively, and the capacity to solve real world problems. Li (2018) stated that PBL can still show its strengths in fostering skill development in terms of interdisciplinary learning, self-directed learning, problem solving skills, creative thinking, communication, as well as enhancing knowledge retention.

The success of the learning process in this study was also helped by the implementation of the learning plan. So the learning process takes place according to the plan and learning objectives. The results of the validation of the learning implementation plan in this study indicate that the RPP developed is valid with an average value of 3.89. Educational change depends on what teachers' 'do' and 'think' as well as what the teachers' 'believe', which ultimately shapes the learning that supports the students' HOTS (Hashim, A. T et al. 2015). Ministry of Education and Culture (2013) that in general the success of the implementation of learning by someone is largely determined by the quality of the plans that they make.

\section{Conclusion}

Biology teaching materials based on local wisdom integrated character education that be implemented in problem based learning models has very significantly influence on students' highlevel thinking. Need analysis must be conducted in learning innovations. This need analysis includes student character analysis, school environment analysis, learning device analysis, and analysis of learning materials. Learning that using local wisdom, character education and PBL models play a positive role in student motivating, cooperation, discipline, fond of reading, valuing achievement, and solving problems in accordance with the expected learning outcomes. 


\section{References}

Ameyaw, Y. (2011). Environmental pedagogies that promote students understanding of integrated science (biology aspect). Journal of Education, 1 (1), 10-15.

Arantes do Amaral, J. A., \& Matsusaki, C. T. M. (2017). The dynamics of connecting universities, non-governmental organizations and community members by means of academic projects directed at people in need. Educational Action Research, 25(2), 280-299.

Benninga, J., S. et al. (2003). "The Re-lationship of Character Education Im-plementation and Academic Achieve-ent in Elementary Schools". Journal of Research in Character Education. September 2003, 1, 1, 19 -32. ProQuest Education Journals.

Berkowitz, M.W. and Bier, M.C. (2007). What Works in Character Education. Journal of Research in Character Education, (Online), 5(1): 29-48.

Davidson, M., et.al. (2007). "Smart and Good Schools". Education Week November 2007.

Folb, B.L., Wessel, C.B., and Czechowski, L.J. (2011). Clinical and academic use of electronic and print books: the Health Sciences Library System e-book study at the University of Pittsburgh. J Med Libr Assoc. 99(3): 218-228.

Gondwe, N., \& Nancy, L. (2014). Scientific and cultural knowledge in intercultural science education: student perceptions of common ground. Res Sci Educ. Springer.

Glynn, S.M., \& Winter, L.K. (2004). "Contextual Teaching and Learning of Science in Elementary Schools". Journal of Elementary Science Education, XVI (2), 51-63.

Glasson, G.E., Mhango, N., Priri, A., \& Lanier, M. (2010). "Sustainability Science Education in Africa: Negotiating Indigenous Ways of Living with Nature in the Third Space". International Journal of Science Education, XXXII (1), 125-141.

Hashim, A. T., Osman, R., Arifin, A., Abdullah, N., \& Noh, N. M. (2015). Teachers' Perception on Higher Order Thinking Skills as an Innovation and Its Implementation in History Teaching. Australian Journal of Basic and Applied Sciences, 9(32), 215-221.

Hadi K, Dazrullisa, Manurung B., Hasruddin. (2018). Development of biological teaching materials based on local wisdom integrated character education and problem based learning models for senior high school in aceh barat-Indonesia. International Journal of Research and Review. 5(9):106-115.

Hadi, K., Dazrullisa, Manurung, B., Hasruddin. (2019). Integration of Local Wisdom and Problem Based Learning Model in the Innovation of Biology Teaching Materials for Senior High School Students in Aceh - Indonesia. International Journal of Humanities Social Sciences and Education (IJHSSE), 6 (1), PP 52-60.

Hartini1, S. Firdausi2, Misbah3, N. F. Sulaeman. (2018). The Development Of Physics Teaching Materials Based On Local Wisdom To Train Saraba Kawa Characters. JPII 7 (2) (2018) 130-137. DOI: 10.15294/jpii.v7i2.14249

Horsley, M., Knight, B., and Huntly, H. (2010). The Role of Textbooks and Other Teaching and Learning Resources in Higher Educationin Australia: Change and Continuity in Supporting Learning. LARTEM 1-Journal Vol. 3(2): 43-61.

Kunter, M., Klusmann, U., Baumert, J., Richter, D., Voss, T., \& Hachfeld, A. (2013). Professional Competence of Teachers: Effects on Instructional Quality and Student Development. Journal of Educational Psychology, 105(3), 805-820.

Komalasari, K., \& Saripudin, D. (2018). The Influence of Living Values Education-Based Civic Education Textbook on Student's Character Formation. International Journal of Instruction, 11(1), 395-410.

Katilmis, A., Eksi, H., and Ozturk, C. (2011). Efficiency of Social Studies Integrated Character Education Program. Educational Sciences: Theory \& Practice. 11 (2):854-859. 
Kim, M. \& W. M. Roth. (2008). Rethinking The Ethics of Scientific Knowledge: A Case Study of Teaching the Environment in Science Classrooms. Education Research Institute. Journal of Environmental Education Summer. 9 (4): 516-528.

Kemendikbud. (2013). Bahan Ajar Training of Training (ToT) Implementasi Kurikulum 2013: Penyusunan Rencana Pelaksanaan Pembelajaran (RPP) SD/ SMP/ SMA/ SMK. Jakarta: Kementrian Pendidikan dan Kebudayaan.

Li, Huichun. (2018). Facilitating Learning through PBL in a Chinese Context: Students' Learning Outcomes and Attitudes. International Journal of Learning, Teaching and Educational Researc. 17 (7):80-93.

Mardhatillah, M., Verawati, V., Evianti, E., \& Pramuniati, I. (2019). Bahan Ajar Interaktif Berbasis Kearifan Lokal Melalui Pendekatan Saintifik Pada Pembelajaran Bahasa Inggris. Genta Mulia: Jurnal Ilmiah Pendidikan, 10(1).

National Research Teacher Assosiation. (2007). Science as Inquiry in the Secondary setting. Arlington Virginia : NSTA Press.

OECD. (2004). learning for tomorrow's world: First results from PIS A 2003. Paris, France: OECD.

OECD. (2007). PIS A 2006 science competencies for tomorrow's world. Volume 1. Paris, France: OECD.

OECD. (2010). PIS A 2009 Results: Executive Summary. www.pisa.oecd.org.

OECD. (2012). PIS A 2012 Results in Focus What 15 Year Olds Know and What They Can Do with What They Know. OECD.

OECD. (2009). PISA 2009 Assessment Framework: Key Competencies in Reading, Mathematics, and Science. USA: OECD-PISA.

Osborne, J. (2013). The 21st century challenge for science education: Assessing scientific reasoning. Thinking Skills and Creativity, 10, 265-279.

Pornpimon, C., Wallapha, A., \& Prayuth, C. (2014). Strategy Challenges the Local Wisdom Applications Sustainability in Schools. Procedia-Social and Behavioral Sciences, 112, 626-634.

Parmin1, Sajidan2, Ashadi3, and Sutikno. (2015). Skill of Prospective Teacher in Integrating the Concept of Science with Local Wisdom Model. Jurnal Pendidikan IPA Indonesia. Indonesian Journal of Science Education. http://journal.unnes.ac.id/nju/index.php/ipii. JPII 4 (2) (2015) 120-126. DOI: 10.15294/jpii.v4i2.4179.

Silaban, R. et al. (2015). Penyusunan Bahan Ajar Kimia Inovatif Materi Laju Reaksi Terintegrasi Pendidikan Karakter Siswa SMA. Jurnal Tabularasa PPS Unimed. Vol. 12 No. 1, April 2015.

Philips, S. 2008. Refleksi karakter bangsa [Reflection on nation character]. Jakarta: Gramedia.

Peterson, C., \& Seligman, M. E. P. (2004). Character strengths and virtues a handbook and classification. Washington, D. C.: APA Press and Oxford University Press.

Sharif, A. \& Gisber, M. (2015). The impact of culture on design instructional and quality. International Journal of Instruction, 8/1, 143-156. Retrieved 16 October, 2017 from http://www.e-iji.net/dosyalar/iji 2015 1 11.pdf.

Suardana, I, N., Redhana, I, W., Sudiatmika A, A, I, A , Rai et all. (2018). Students' Critical Thinking Skills in Chemistry Learning Using Local Culture-Based 7E Learning Cycle Model. International Journal of Intruction. Vol. 11, No. 2, pp 400-412.

Sugiyo, R \& Purwastuti, A. L. (2017). Local Wisdom-Based Character Education Model in Elementary School in Bantul Yogyakarta Indonesia. Sino-US English Teaching, May 2017, Vol. 14, No. 5, 299-308.

Sari, S. M., \& Mardhatillah, M. (2018). Perbedaan Pengaruh Metode Inkuiri Dengan Metode Konvensional Terhadap Hasil Belajar Bahasa Indonesia. Bina Gogik: Jurnal Ilmiah Pendidikan Guru Sekolah Dasar, 5(2).

Triatmanto. (2010). Tantangan Implementasi Pendidikan Karakter di Sekolah. Yogyakarta: Cakrawala Pendidikan.

Tosun, C. \& Taskesenligil, Y. (2011). The effect of problem based learning on student motivation toward chemistry classes and on learning strategies. Journal of Turkish Science Education, 9 (1), 104-125. 